\title{
Frihed til kærlighed hos Luther og Kierkegaard
}

\author{
Post.doc ph.d. Claudia Welz
}

\begin{abstract}
You shall love thy neighbour as yourself". How does commanded love turn into the praxis of loving? According to Kierkegaard, works of love are not just grounded in human agency and capability, but are done in the Spirit of love. The key words of Kierkegaard's explanation - 'spirit', 'interiority', 'gift' and 'debt' - are decisive also for the Pauline-Lutheran tradition. This tradition holds that the human being becomes free to love his neighbor only if he has been freed from self-centredness. Yet, what does that imply for the view of the person, who is simul iustus et peccator, at once a sinner and justified, at once 'the old Adam' and 'a new creature'? The anthropological implications are controversial, especially in regard to the relation between the 'inner' and the 'outer', the 'old' and the 'new' person, the sinner's nature and his self-transcendence. Kierkegaard's insights could contribute to the clarification, if not correction, of some notorious problems that belong to $\mathrm{Lu}$ ther's heritage.
\end{abstract}

Key words: Luther - Kierkegaard - love - freedom - faith - works - sin affliction - Abraham - justification - spirit - interiority - gift - debt new/old creature - conscience - hiddenness.

Formålet med denne artikel er at fortolke Kierkegaards Kjerlighedens Gjerninger i lyset af den paulinsk-lutherske tradition han selv står i $o g$ at vise, hvordan Kierkegaard forsøger at forny og reformere denne tradition. Som titlen fortæller, fokuserer jeg på menneskesynet og gudsforholdet. Frihed til kærlighed er ikke en selvfølgelighed for os. Vi skal elske næsten - men kan vi det, og hvis ikke, hvorfor ikke? Hvad skal der til, for at vi bliver i stand til at elske i frihed?

Jeg vil først minde om de vigtigste teser fra Luthers traktat $O m$ et kristenmenneskes frihed og så sammenligne dem med Kierkegaards svar på disse spørgsmål. 


\section{Luthers frihedstraktat (1520): \\ Et kristenmenneskes dobbelte natur og $(\mathrm{u})$ frihed}

Luthers hovedtese om et kristenmenneske er, at det er en fri herre over alle ting, ingen undergivet, men samtidig i alle ting en træl, enhver undergivet og skyldigt at gøre tjeneste. ${ }^{1}$ Luthers tese nummer to er, at et kristenmenneske har en dobbelt natur: på den ene side er det udvortes eller som det ydre gamle menneske legemligt og består af kød og blod; på den anden side er det indvortes eller som det indre nye menneske åndeligt (2).

De to teser $\mathrm{i}$ indledningen bliver udfoldet i det følgende: Teserne 3-18 handler om det indre og teserne 19-30 om det ydre menneske. Det indre menneskes fribed er frihed fra..., nemlig fra gode gerninger og kirkelov og alle krav $(4,6)$, da synden tilgives gennem tro alene og da Kristus er alle buds opfyldelse. Desuden er det frihed fra alt ydre (3), for hvad skader det sjælen, at kroppen er fangen, syg og svag, tørster og lider? Sjælen kan undvære alt undtagen Guds trøstende ord, mener Luther $(5,6,8)$. Derfor er det indre menneske frit fra dets fordærvelse, når det kommer bort fra sig selv (6). Ved troen bliver det åndeligt herre over alle ting, som nu må tjene det gode (Rom 8), selv døden må tjene og kan ikke skade dets salighed $(15,18)$.

Men det ydre menneske er en træl. Ifølge Luther består dets trældom deri, at det er undergivet loven (Gal 4), skal gøre gode gerninger og elske andre (Rom 13) - men ikke for at blive fromt (19, 22). I dette legemlige liv skal kroppen og kødets modstræbende vilje, som vil søge, hvad den har lyst til, styres $(20,22)$. Det ydre menneskes såkaldte traldom kan dog samtidig ses som dets frihed til..., nemlig til kærlighed. Et kristenmenneske tjener næsten af fri kærlighed (26), skriver Luther. Mens troen er kilden til kærlighed, er kærlighed kilden til et frit, villigt, muntert liv (27). Kærligheden søger ikke sit eget, men hvad næstens er (1 Kor 13), og så strømmer Guds gaver fra den ene til den anden (29). Forudsætningen for denne frihed er, at personen må være god forud for alle gode gerninger, der udgår fra ham som god frugt udgår fra et godt træ (23). Kærlighedens gerninger viser udvortes, hvordan personen er (24).

Luther konkluderer med den dobbelte tese, at et kristenmenneske ikke lever i sig selv, men i Kristus gennem tro og i sin næste gennem kærlighed (30). Denne sluttese implicerer to slags frihed: for det før-

1. Jf. Martin Luther, "Tractatus de libertate christiana" (WA 7, 49-73), oversat som "Om et kristenmenneskes frihed", Luthers Skrifter i Udvalg, bd. 1: De reformatoriske Hovedskrifter (Århus: Forlaget Aros 21980), 282-316. Jeg citerer tesernes numre i parentes. Her (1). 
ste frihed som Guds gave, nemlig troen, for det andet frihed som menneskets opgave, nemlig næstekærlighed, som udspringer af troen.

Jeg vil om lidt præsentere og diskutere tre problemer, der knytter sig til Luthers position (se afsnit 3). Men først vil jeg gøre opmærksom på, hvor mange motiver Kierkegaard har fælles med Luther. De fleste af dem stammer fra Det Nye Testamente. Kierkegaards taler om Kjerlighedens Gjerninger støtter sig nemlig nøjagtig på de samme steder som Luthers Tractatus. At Kierkegaards bog har et luthersk præg er ikke så mærkeligt, fordi det er hævet over enhver tvivl, at Kierkegaard er opdraget $i$ et protestantisk miljø og har læst en del af Luthers skrifter, især hans prædikener. ${ }^{2}$ Kierkegaards læsning af Luthers prædikener og andre skrifter skal dog ikke benyttes som begrundelse for sammenligningen. Sigtet af min artikel er ikke en historisk rekonstruktion af Kierkegaards forhold til Luther, men en systematisk fremstilling af ligheder og forskelle i deres teologi, antropologi og etik.

\section{Kierkegaards Kjerlighedens Gjerninger (1847): Næstekærlighedens kilde - Guds given sig selv}

Kierkegaard er på flere punkter enig med Luther i sin karakteristik af kærligheden.

1. Næstekærlighedens kilde er Guds given sig selv og Guds kærlighed er forbilledet for menneskers kærlighed. ${ }^{3}$ I bogens begyndelse

2. For god ordens skyld gøres der opmærksom på, at Kierkegaard i al fald har læst Luthers prædikener i form af et sammendrag af kirke- og huspostillerne, jf. En christelig Postille, sammendragen af Dr. Morten Luthers Kirke- og Huuspostiller, overs. af J. Thisted, bd. 1-2 (København 1828, auktionsprotokoll: ktl. 283). Det gjorde han allerede i 1842-43, jf. anden del af Enten-Eller (SKS 3), udg. af Søren Kierkegaard Forskningscenteret (København: Gads Forlag 1994), 123. I 1847, da han skrev Kjerlighedens Gjerninger $(=K G)$, findes der et par henvisninger til postillen, men det er først fra november-december 1847, at han indleder den kontinuerlige prædikenlæsning ( $K G$ udkom den 29. september, jf. Kommentarbind SKS.K9, 7). Flere bemærkninger i hans Papirer (herefter Pap.) vidner om hans enighed eller uenighed med Luther, jf. M. Jamie Ferreira, Love's Grateful Striving: A Commentary on Kierkegaard's Works of Love (Oxford/New York: Oxford University Press 2001), 248-253. Mere generelle oplysninger om Kierkegaards forhold til Luther og lutheranismen findes i følgende to artikler: Hermann Deuser, "Kierkegaard und Luther", Theologie und Kirchenleitung: Festschrift Peter Steinacker zum 60. Geburtstag (Marburger theologische Studien, bd. 75), red. Hermann Deuser m.fl. (Marburg: Elwert 2003), 79-88; Johannes Sløk, “Kierkegaard og Luther", Kierkegaardiana 2 (1957), 7-24.

3. Sidetal i parentes refererer til Søren Kierkegaard, Kjerlighedens Gjerninger (SKS 9), udg. af Søren Kierkegaard Forskningscenteret (København: Gads Forlag 
findes en bøn med en trinitarisk struktur, der viser det: "Hvor skulle der kunne tales retteligen om Kjerlighed, hvis Du var glemt, Du Kjerlighedens Gud, af hvem al Kjerlighed er i Himmelen og paa Jorden; Du, der Intet sparede, men gav Alt hen i Kjerlighed; Du, der er Kjerlighed, saa den Kjerlige kun er hvad han er ved at være i Dig! [...] $\mathrm{Du}$, der gjorde det aabenbar, hvad Kjerlighed er, Du, vor Frelser og Forsoner, som gav Dig selv hen for at frelse Alle! [...] Du Kjerlighedens Aand, Du, som Intet tager af Dit Eget, men minder om hiint Kjerlighedens Offer, minder den Troende om at elske, som han er elsket, og sin Næste som sig selv!” (SKS 9, 12) Det er slående, at Luthers to teserækker i hans skrift Om et kristenmenneskes fribed også er opbygget med en trinitarisk struktur. ${ }^{4}$ Ligesom Luther og Paulus beskriver Kierkegaard den rette kærlighed som en kærlighed der ikke søger sit eget, men giver sig selv til en anden (jf. Tale II.IV). Kierkegaard bruger også kilde-metaforen for at illustrere, hvordan kærlighed er overstrømmende, og for at referere til dens oprindelse: "Som den stille Søe grunder dybt i de skjulte Kildevæld, hvilke intet Øie saae, saaledes grunder et Menneskes Kjerlighed endnu dybere, i Guds Kjerlighed" (Tale I.I; SKS 9, 17).

2. Luthers henvisning til loven og kærlighedsbudet passer godt til Kierkegaards beskrivelse af kærlighed som en uopsættelig pligt (jf. Tale I.II.A-C, I.IV og I.V) og lovens fylde (jf. Tale I.III.A). Hvordan bliver kærlighedens bud til kærlighedens praksis? Kierkegaard vil ikke bygge på følelser, dyd og menneskelig formåen. Hvis kærlighedens gerninger ikke grunder i vores egen handlingskraft, hvordan kan de så alligevel realiseres?5 Kierkegaard forklarer det ved hjælp af nøgleord 'ånd', 'gæld' og 'gave'. Da Gud elskede os, før vi overhovedet kunne begynde at elske ham, begynder ethvert menneske i forhold til Gud "med en uendelig Gjeld" (Tale I.III.A; SKS 9, 106). Men Kierkegaard taler ikke bare om, at den, der bliver elsket, ved at blive elsket kommer i gæld. Han afviser snarere tanken om, at kærlighed, der er vist os, nu skal afbetales med kærlighed, som om kærlighed var penge og som om et kærlighedsforhold var et regnskabsforhold. Han betoner, "at dette er Kjerlighedens Eiendommelige: at den Elskende ved at give, uendeligt, kommer - i uendelig Gjeld" (Tale I.V; SKS 9, 177).

2004). Bogen består af første og anden følge. Når bogen citeres, nævnes først følgen og så den enkelte tale: f.eks. II.IV refererer til tale IV i anden følge.

4. Dette er påvist af Steffen Kjeldgaard-Pedersen, "Jene christliche Freiheit, unser Glaube", Caritas Dei: Beiträge zum Verständnis Luthers und der gegenwärtigen Ökumene (Festschrift für Tuomo Mannermaa zum 60. Geburtstag), red. Oswald Bayer m.fl. (Helsinki: Luther-Agricola-Gesellschaft 1997), 222-242.

5. Jf. Claudia Welz, "How to Comprehend Incomprehensible Love? Kierkegaard Research and Philosophy of Emotion", Kierkegaardiana 24 (2007), 261-286. 
Hele talen drejer sig om "Vor Pligt at blive i Kjerlighedens Gjeld til hverandre". Eftersom kærlighed er uendelig og det er umuligt at afbetale en uendelig gæld uden at endeliggøre og begrænse kærligheden, er det "en Ære, at blive i den" (SKS 9, 177). Kærlighedens element er uendelighed, uudtømmelighed, umålelighed - og derfor skal den ikke dvæle ved sig selv, men skænkes videre.

3. I den første tale i første følge (I.I) illustrerer Kierkegaard en persons forhold til sine gerninger med det samme billede som Luther: et træs forhold til dets frugter. Ydermere tager han Luthers skelnen mellem indvorteshed og udvorteshed op, når han beskriver den evige kærligheds såkaldte "Fordoblelse i sig selv" (SKS 9, 278). Når det evige er $\mathrm{i}$ et menneske, fordobler det sig således, at det i samme øjeblik går ud af sig selv og er i sig selv, dvs. det bevæger sig samtidig i retningen ind efter og retningen ud efter. Derfor er kærlighed hvad den gør; dens usynlige væsen svarer til dens synlige gerninger. Når kærlighed giver frimodighed, så betyder det ikke bare, at den kærlige har frimodighed i sig selv, men også, at den ved sit væsen gør andre frimodige (jf. SKS 9, 278f). Der er her en strukturel lighed til Luthers beskrivelse af Guds retfærdighed, der i dens egenskab af iustitia retfærdiggør synderen.

Men, kunne man indvende, har Guds egenskaber egentlig samme kvalitet som menneskers? Kan menneskelig kærlighed udføre det samme som Guds kærlighed? Er der ikke en afgørende forskel mellem de to? Luthers tese nr. 28 fra Heidelbergteserne -Amor Dei non invenit sed creat suum diligibile, Amor hominis fit a suo diligibili ${ }^{6}$ - beskriver denne forskel ved at sige, at Guds kærlighed ikke finder men skaber det, den elsker, mens menneskets kærlighed bliver til ved det, den elsker. Kierkegaard betoner også, at intet menneske er identisk med kærlighed, men det kan kun elske, når det befinder sig i kærlighed, og at et menneskes kærlighed grunder i Guds kærlighed. Han understreger samtidig, at den kærlighed, der forbinder det ene menneske med et andet, ikke er en anden kærlighed end Guds egen kærlighed. Ja, Gud selv, som er kærlighed, er kærlighedens bånd, der forbinder mennesker med hinanden og derved det timelige og det evige. Siden Gud er, som Kierkegaard kalder det, "Mellembestemmelsen" i et kærlighedsforhold mellem mennesker, er forholdet til Gud det inderligste og fortroligste forhold overhovedet (jf. SKS 9, 111 og 152154). Denne idé har store antropologiske og teologiske konsekvenser, der viser sig i menneskesynet. Og her er det snart slut med enigheden

6. Jf. Martin Luther, "Disputatio Heidelbergae habita (1518)" (WA 1, 353-366), oversat som "Heidelbergtheserne", Luthers Skrifter $i$ Udvalg, bd. 1: De reformatoriske Hovedskrifter (Århus: Forlaget Aros ${ }^{2} 1980$ ), 70-94. 
mellem Kierkegaard og Luther. Lad os kaste et blik på de kontroversielle punkter.

\section{Menneskesynet: \\ Kontroversielle punkter og Kierkegaards korrekturer}

\section{Forholdet mellem det 'indre' og det 'ydre' menneske}

Strukturen i Luthers traktat kan føre til en misforståelse, nemlig at mennesket er sammensat af en indre og en ydre del, som er vidt forskellige. Hvordan skal hans tese om menneskets dobbelte natur og (u)frihed fortolkes? Er kun det indre menneske frit, mens det ydre menneske forbliver en træl? Eller er et menneske begge dele på samme tid, altså et levende paradoks? Det er svært at nægte spændingen mellem de to teserækker og de to måder, mennesket er beskrevet på.

Et elegant forsøg på at holde begge dele sammen er Eberhard Jüngels udlægning af Luthers lille skrift. Ifølge Jüngel ${ }^{7}$ er både det indre og det ydre menneske frit på én måde og en træl på en anden måde. Det indre åndelige menneske er befriet fra sig selv og kan derfor være 'ude af sig selv' - extra se, dvs. det åndelige menneske kan forholde sig til sig selv og andre, mens det ydre kødelige menneske altid allerede er ved sig selv og derfor kan det ikke komme til sig selv og andre. Den troende forlader bogstaveligt talt sig selv, dvs. han stoler på Gud og er derfor fri fra bekymringen om sig selv, fri til kærlighed, fri til at blive en træl, der frivilligt er undergivet alle. Den, der ikke tror, føler sig fri fra denne forpligtelse, men forbliver sin egen træl, fordi han ikke kan forlade sig selv i sin selvindkrogethed. I det ideale tilfælde svarer det ydre til det indre menneske. I dette tilfælde regerer det indre menneske over det ydre menneske og kan bruge det som instrument til at fuldføre kærlighedens gerninger.

Jüngels fortolkning har vidtrækkende konsekvenser. Betyder det ikke i sidste ende, at det ydre bliver indre, at kødet bliver åndeligt, eller med andre ord: at modsætningen forsvinder, så snart synderen forvandler sig til en troende, når mennesket vender sig fra det ydre til det indre? Problemet er bare, at Luthers traktat handler om det kristne menneskes frihed, der er indre og ydre, uden at de to kan opløses i hinanden - i hvert fald ikke i dette jordiske liv. De to teserækker kan ikke fordeles sådan, at den troende er identisk med det indre menneske, mens synderen er identisk med det ydre menneske, heller ikke, når man siger simul iustus et peccator, for menneskets legemlighed kan

7. Jf. Eberhard Jüngel, Zur Freiheit eines Christenmenschen. Eine Erinnerung an Luthers Schrift (München: Kaiser ${ }^{3} 1991$ ), især 70f, 76f, 83f, 97f, $101 \operatorname{og} 103$. 
ikke som sådan klassificeres som synd. Jüngels fortolkning kan læses som et forsøg på at løse dette problem. Han påpeger, at det indre menneske faktisk er ufrit og har fortabt sin bevægelsesfrihed, fordi det eksisterer som dobbeltgænger af det ydre menneske (jf. Jüngel 1991, 81). Det er alene gennem Guds ord, at det indre menneske, som forfejler sig selv, er kaldt ud og kan befries af sin selv-fiksering (jf. Jüngel 1991, 82). Efter min mening er det forvirrende og misforståligt, at Luther betegner det nye menneske som det indre, åndelige og det gamle menneske som det ydre, legemlige. Problemet består jo ikke bare i, at kroppen kommer til kort i sådan en antropologi. Problemet består også i, at man kommer i fare for at overse sjælens tvetydighed, der er en del af det tvetydige sammenspil af det indre og det ydre i en synder, der først ved troen opdager sin synd. Desuden er det elegant, men vildledende at sige, at det indre menneske kan forholde sig til og forlade sig på andre, mens det ydre menneske ikke kan det, fordi det forbliver alene med sig selv som homo incurvatus in se $^{8}$

Her vil jeg fastholde Kierkegaards indsigt $i$, at vi altid forholder os både til os selv og til andre. Problemet er ikke en mangel på forhold, men det, at et forhold kan degenerere til et misforhold. Implikationen af dette er en anden indsigt, nemlig at inderlighed ikke er et indre rum i sjælen, der er adskilt fra et andet rum i den ydre verden, hvor vi kan bevæge os kropsligt, men snarere en måde at vare til og at handle $p a ̊$, der omfatter selvet, verden og andre mennesker. ${ }^{9}$ Kierkegaard fremhæver kærlighedens inderlighed, der netop forbinder det materielle og det immaterielle, fordi både kroppen og sjælen er involveret i den.

Kierkegaard kan korrigere en 'dualisme' af det ydre, legemlige på den ene side og det indre, åndelige på den anden side, idet han ikke længere placerer ånden $\mathrm{i}$ en indre verden, men forstår ånden som det tredje, der knytter kroppen til sjælen og virker ved at forene og aktivere de to i en livlig, foranderlig syntese. Alligevel findes der også en reception af Paulus' modsætning af sarx og pneuma hos Kierkegaard. Virker der så to slags ånd i mennesket - Guds Helligånd og menne-

8. Jf. Jüngel ${ }^{3} 1991,80$ : “Gerade der innere Mensch kann sich selbst verlassen, so daß er auf andere eingehen und sich auf sie einlassen, ja verlassen kann. [...] Der inwendige Mensch existiert in der Wende von innen nach außen. Deshalb kann er sich von sich selbst abwenden lassen. Das aber kann der äußere Mensch nicht, jedenfalls nicht ohne den inneren. [...] Er bleibt bei sich selbst, wohin er auch geht. Er ist der alte. Er ist es schon immer. Der innere Mensch hingegen ist im Werden und insofern der neue Mensch, der dann und nur dann alt wird, wenn er bei sich selbst bleibt; und dann wird er notwendig alt."

9. Jf. Arne Grøn, "Subjectivity, Interiority and Exteriority: Kierkegaard og Levinas", Despite Oneself: Subjectivity and Its Secret in Kierkegaard and Levinas, red. Claudia Welz \& Karl Verstrynge (London: Turnshare 2008), 11-30. 
skets egen ånd, og hvis ånd virker da i kærlighed? Her viser der sig en fordel ved Kierkegaards model over for Luthers. Idet Kierkegaard ikke reserverer begrebet 'ånd' til det nye menneske, der ikke kan gøre noget af sig selv, men ligesom er styret af Guds virksomme Helligånd, forhindrer Kierkegaard, at den menneskelige ånd bliver blandet sammen med den guddommelige ånd. Ånden som en antropologisk bestemmelse er ikke nødvendigvis kærlig - det er den kun, hvis den virker 'i' eller 'sammen med' Guds ånd. Hvis menneskets ånd ikke er kærlig, så er hele selvet selvisk - ikke bare dets legeme. I kærligheden er Helligånden denne "Mellembestemmelse", der bestemmer det ene og det andet menneske, som begge to er ånd, men er det hver for sig individuelt.

Det skal ikke forties, at Kierkegaards konception også har sine særlige problemer. Ækvivokationen $\mathrm{i}$ åndsbegrebet er forholdsvis harmløs. Det mere alvorlige problem ligger i Kierkegaards skelnen mellem "Aandens Kjerlighed" - som er enten Guds eller et kristenmenneskes næstekærlighed - og "Forkjerlighed" - som ifølge Kierkegaard er en egoistisk præference for en enkel repræsentant af det andet køn eller venskab, der udelukker andre til fordel for alle, der ligner og sammenslutter sig med en selv. Er det rigtig, at det er umuligt at elske ens kæreste eller ven uden selvoptagethed? Kierkegaard synes, at kun næstekærlighed er selvfornægtende, mens der ligger selvkærlighed i det, at den elskede er kaldt "det andet Selv, det andet Jeg" (SKS 9, 60). Når han opstiller en sådan kontrast og hævder, at "kun i Kjerlighed til Næsten er det Selv, som Elsker, reent aandeligt bestemmet som Aand", mens Jeg'et i erotisk elskov er "sanselig-sjælelig-aandelig-bestemmet" (SKS 9, 63), glemmer Kierkegaard sin egen indsigt $i$, at vi aldrig møder ren ånd, når vi møder et andet menneske. ${ }^{10}$ Menneskelig individualitet er også fysisk og psykisk bestemt, og ånden er ikke en tredje del, der kan isoleres fra menneskets andre dele, men er så at sige 'katalysatoren', der igangsætter og fremskynder hele processen, hvori et menneske udvikler sig og vokser sammen med sig selv.

For at være fair imod Luther må det indrømmes, at han i andre skrifter med større succes har forsøgt at overvinde de klassiske konstitutionstrichotomier, der opdeler mennesket i corpus/caro - anima spiritus eller sensus - ratio - spiritus. ${ }^{11}$ Han kritiserer dem ikke, når der er tale om et menneskes forhold til verden, men han gør op med dem, når der er tale om et menneskes forhold til Gud, dvs. om tro eller vantro. Han gør det blandt andet af eksegetiske grunde, fordi det

10. Jf. Claudia Welz, Love's Transcendence and the Problem of Theodicy (Tübingen: Mohr Siebeck 2008), 168-172.

11. Jf. Wilfried Joest, Ontologie der Person bei Luther (Göttingen: Vandenhoeck \& Ruprecht 1967), 163ff. 
er det hele menneske, som ifølge Paulus enten lever åndeligt, dvs. konformt med Guds Helligånd, eller syndigt, dvs. følger sine egne modstridende forestillinger. Syndens problematik bliver derfor det næste punkt, der skal drøftes. Hvad er forholdet mellem det 'gamle' og det 'nye' menneske?

\section{Forholdet mellem det 'gamle' og det 'nye' menneske}

I mellemtiden er det allerede blevet klart, at det ikke holder, hvis det kun er det 'indre' mentale liv, der identificeres med det nye menneske, mens kroppen forbliver det gamle menneske. Hvis mennesket ses holistisk, dvs. som en helhed, så kan synden ikke reduceres til det 'ydre' legemlige liv, og friheden fra synden ikke til det 'indre' sjælelige liv. Synden angår alt, et menneske er og gør, og det samme gælder for befrielsen fra synden. Synderens ufrihed består i hans selviskhed, hans uformåen til at søge noget andet end sit eget. Synderens befrielse består i hans omvending til det andet, en ændring af fokus for opmærksomhed og udskiftning af formål for det, han vil og gør. Kun en, der er befriet fra bekymringen om sig selv, er fri til omsorg for næsten. Ifølge Luther forbliver der en spænding mellem det gamle og det nye menneske i dette liv, men det gamle skal forgå.

Fornyelse er ikke noget vi kan give os selv, men noget, som sker med os og forandrer os, så at det hele menneske til sidst er fornyet. Det er den 'partiale', 'effektive' eller 'kvantitative' betydning af Luthers formel simul iustus et peccator ${ }^{12}$ : synden er udgangspunktet eller terminus a quo, retfærdighed er målsætningen eller terminus ad quem i et kristenmenneskes liv. Luther ser hele livet som en overgang og progression fra det gamle til det nye, dog er det ikke bare fremskridt, men en vej, der indebærer tilbagefald til det gamle, regression fra retfærdighed til synden. Problemet er så, at man hverken kan måle synden eller retfærdigheden, og at vi ikke selv kan skabe kontinuiteten mellem det gamle og det nye, fordi vi er fanget ind i det, vi allerede er og gør, uden at vi selv kan ændre det. Det, der ændrer noget, er Guds skabende ord, der taler til os og opbygger os. Selvom vi ikke er retfærdige, men forbliver syndere i alt vi er og gør, tilregnes synden ikke. Det er den 'totale', 'imputative' eller 'kvalitative' betydning af Luthers simul-formel. Dobbeltheden i dens betydning sætter spørgsmålstegn ved vores 'natur': Er ufriheden blevet til vores natur, som derfor er fuldstændig korrumperet - natura corrupta? Eller er der en rest tilbage, der ikke er påvirket af denne korruption? Hvordan for-

12. WA 40, 368, 26. Jf. Andrew J. Burgess, "Kierkegaard's Concept of Redoubling and Luther's Simul Justus", Works of Love (International Kierkegaard Commentary, bd. 16), red. Robert L. Perkins (Macon: Mercer University Press 1999), 3955. 
holder den 'gamle' natur, som kristenmennesker deler med alle andre mennesker, sig til den 'nye' skabning?

Når vi taler om menneskets natur, så taler vi om, hvordan dets væsen er - nu og senere. Men skal vi overhovedet tale så generelt om, hvordan mennesket er? Både Luther og Kierkegaard er mere interesseret i menneskets tilblivelse end i dets tilværelse, mere i dets vorden end i dets væsen. Hvis vi samler opmærksomheden på det, mennesket skal blive, så samler vi opmærksomheden på det, der gør, at mennesket bliver til det, det skal være - og på det, der forhindrer denne $ø$ nskede udvikling. Her kommer tvetydigheden af menneskets (u)frihed ind i billedet. Hvis ikke vi kan hjælpe os selv, når vi slutter os inde i os selv, så er vi i vor egen afmagt afhængige af det, der kommer udefra og forløser os. Luther og Kierkegaard er enige om, at det er nødvendigt at komme ud over sig selv for at blive sig selv - for at blive et selv, der er frit til kærlighed.

Luther påstår, at mennesket forløses mere passive, uden at kunne gøre noget for det. Det er Gud alene, der gør og fuldfører alt det gode. Hvis mennesket bringer til udførelse, hvad det formår af sig selv, så begår det en dødssynd ${ }^{13}$, fordi menneskets handlinger kommer i konkurrence med Guds handlen. Hvis mennesket vil tilregne sig selv fortjenesten for, hvad det har gjort, så er dets retfærdiggørelse muteret til selvretfærdiggørelse. Luther kan ikke acceptere menneskelig frihed i forholdet til Gud, fordi han forstår frihed som en totalbestemmelse af mennesket, ikke alene som en sjælesevne, og han nægter menneskets mulige medvirken til frelsen, fordi vi ikke når frem til troens frelsesvished, hvis der er en mulighed for, at vi selv kan bringe frelsen i fare. ${ }^{14}$ Guds nåde kan derfor aldrig blive en del af den nye skabning, og hans verbum externum kan aldrig blive et internt ord vi kunne sige til os selv. Bo Kristian Holm har fortolket Luthers traktat således, at Luther udnytter den oldkirkelige to-natur-kristologi til at udforme en slags "to-natur-antropologi": den kristne er et "to-naturmenneske", der både består af sig selv og Kristus, af den gamle og den nye Adam (Holm 2006, 125f). Hvis det er korrekt, så er Gud integreret i mennesket.

Det sympatiske anliggende er at vise virkningen af Guds nærvær i mennesket, der forandrer dets eksistens. Men hvad vil det sige, at menneskets natur forbedres gennem Guds nærvær? Problemet er, at man nemt kommer til at undervurdere synden, som er der stadigvæk,

13. Jf. 13. tese i Heidelbergteser fra 1518: "Liberum arbitrium post peccatum est de solo titulo, et dum facit quod in se est, peccat mortaliter."

14. Jf. Bo Kristian Holm, "Den frie vilje er kun til af navn: Luther, Melanchthon og Erasmus", Nåden og den frie vilje, red. Bo Kristian Holm \& Else Marie Pedersen (Frederiksberg: Forlaget Anis 2006), 27f, 119-152. 
og til at overvurdere menneskets formåen til at forbedre sig selv med Guds hjælp. Det sidste kræver en klart afgrænset kompetencefordeling mellem Gud og mennesket i deres cooperatio. Måske er det mere adækvat at gøre op med menneskets opdeling i to naturer. Vi skal blive menneskelige mennesker, ikke mere, ikke mindre. Som sådan er vi ikke splittet op i en menneskelig og en guddommelig del. Det, at Gud er nærværende, betyder ikke, at vi participerer i hans natur eller at vores natur bliver fornyet på den måde, at den menneskelige ånd bliver identisk med Guds ånd. Derfor er jeg uenig med den finske Lutherforskningens repræsentanter, der hævder menneskets guddommeliggørelse, dets theosis. ${ }^{15}$ Konsekvensen af en teologisk antropologi, der forudsætter, at mennesket er guddommeliggjort, er en sammenblanding af det forensiske og det effektive aspekt af dets retfærdiggørelse. ${ }^{16}$

Det problem, Kierkegaard arver fra den lutherske tradition, er altså problemet med, hvordan sammenhængen mellem synderens ufrihed og et kristenmenneskes frihed skal forstås, og i hvilken forstand, hvis overhovedet, mennesket kan samarbejde (cooperare) med Gud i forbindelse med frelsen, dets befrielse til friheden. På den ene side forklarer Luther, at mennesket ikke er passivt på samme måde som en sten eller et stykke træ. Når Gud virker i det, handler dets befriede vilje heller ikke under tvang. Ingen kan tro og elske mod sin vilje. Derfor er det problematisk, at Luther på den anden side kan bruge billedet af et trækdyr, der bevæger sig derhen, hvor kusken vil, for at beskrive menneskets forhold til Gud eller Satan (WA 18, 635). Her får man et indtryk af, at mennesket er udleveret til andre magter og må gøre, hvad de siger. Men er mennesket kun et handlende subjekt i forhold til verden?

Kierkegaard undgår dette problem, fordi han ikke fører ufriheden tilbage til menneskets underkastethed under fremmede magter, der er større end det. I Begebet Angest forklarer den pseudonyme forfatter Vigilius Haufniensis ufrihed som et frihedens fænomen. ${ }^{17} \mathrm{Han}$ udfolder, hvordan friheden indvikler og forfejler sig selv. Det er en 'hil-

15. Jf. Risto Saarinen, “Theosis”, Theologische Realenzyklopädie 32 (2002), 389-393.

16. Jf. Tuomo Mannermaa, Christ Present in Faith: Luther's View of Justification, red. Kirsi Stjerna (Minneapolis: Fortress Press 2005), og artiklerne i Union with Christ: The New Finnish Interpretation of Luther, red. Carl E. Braaten \& Robert W. Jenson (Grand Rapids: Eerdmans 1998).

17. Søren Kierkegaard, Begrebet Angest (i: SKS 4), udg. af Søren Kierkegaard Forskningscenteret (København: Gads Forlag 1997), 307-461, Caput IV (436 fodnote 1$)$. 
det' frihed. ${ }^{18}$ Når han understreger, at friheden ikke begynder som et liberum arbitrium, der ligeså godt kan vælge det gode som det onde (jf. SKS 4, 414f), minder dette om Luthers skrift De servo arbitrio. ${ }^{19}$ Vi har ikke et frit valg (liberum arbitrium) her, fordi viljen (voluntas) er bundet til det vi vil, og kun friheden til at gøre det gode fortjener at blive kaldt 'frihed'. Når man vil noget, står man ikke på afstand af det man vil, tværtimod går man op i det, er involveret deri, kaster sig ud $i$ et engagement. Det står ikke en frit for enten at vælge det gode eller at gå imod det gode, fordi man er bundet af det, man vender sig mod og har sig selv at kæmpe med. ${ }^{20}$ Alligevel hævder Kierkegaard, at der ligger en frihed i det, at vi overhovedet kan forholde os til det vi gør - på mange forskellige måder. Vi er ikke låst fast i en given situation, så længe der har været en mulighed for at kunne handle anderledes, end vi faktisk gjorde. Selvforholdets frihed er dette at kunne sætte sig på afstand, selvom man opdager sig bundet og berørt. Det er ikke det samme som indifferens. Det, man interesserer sig for, 'fanger' og 'fikserer' en - men muligheden for selvdistance og selv-transcendens, der er indbygget i selvforholdet, er frihedskonstituerende. Frihed er i det bedste tilfælde et lykkeligt samspil mellem, hvad vi gør og hvad der sker med os. Et dyr er ikke frit på samme måde.

Hvis man vil genfortolke Luthers tanke om, at vi forløses mere passive, i lyset af Kierkegaards overvejelser, er man konfronteret med spørgsmålet, om denne passivitet stadig findes. Er ikke alene det at kunne forholde sig til sig selv en fri handling, og betyder det ikke, at vi er konstant aktive? Det, at vi er fri- og retfærdiggjorte må selvfølgelig betyde, at vi nu skal handle som frie skabninger. Men vi finder os (passivt) sat ind i aktiviteten, uden at vi selv har placeret os dér. Friheden er givet - som en opgave. Dens givethed er vores kastethed ind i den. Vi kan ikke afvise det at være frie og kommer ikke udenom at svare i denne frihed, som vi ikke har selv givet til os. Det er det ene aspekt. Det andet aspekt er, at der også ligger en passivitet i det, at vi

18. Jf. Johannes Adamsen, "Den hildede frihed - Kierkegaard", Nåden og den frie vilje, red. Bo Kristian Holm \& Else Marie Wiberg Pedersen (Frederiksberg: Forlaget Anis 2006), 295-314.

19. Vigilius Haufniensis' kritik af liberum arbitrium refererer dog ikke direkte til De servo arbitrio. Det bygger på en diskussion, som Gottfried W. Leibniz fører i sin Theodicée (jf. f.eks. notesbog 13:23 i SKS 19, 391f, fra 1842-43), jf. s. 414: “At lade Friheden begynde som et liberum arbitrium (der intetsteds har hjemme, jfr. Leibnitz), der ligesaa godt kan vælge det Gode som det Onde, er fra Grunden af at umueliggjøre enhver Forklaring." Herudover henviser Kierkegaard til H.N. Clausens forelæsninger, jf. notesbog 1 , hvor der om liberum arbitrium citeres fra Formula Concordiae (i SKS 19, 70, marginen).

20. Jf. Arne Grøn, "Frihed i religionsfilosofisk perspektiv", Frihed: idé og virkelighed, red. Arne Grøn \& H.C. Wind (København: Forlaget Anis 1989), 9-30. 
ikke kan befri os, når vi bliver fanget ind af vores frihed. Vi ikke kan befri os fra frihedens misbrug, men har brug for, at vi bliver sat ind $i$ den rette frihedsbrug. Her viser det sig, hvor begrænset vores frihed er. Det hjælper ikke at kalde hele menneskets natur 'korrupt', og det hjælper heller ikke at postulere en fri og en ufri natur i det. Det gælder om at forstå den tvetydighed, der ligger i friheden selv som fænomen, dvs. i vores måde at erfare frihedens 'natur' på, som kan skifte form og forvandle sig til ufrihed.

\section{Forholdet mellem tro og karlighed}

Det tredje kontroversielle punkt er forholdet mellem tro og kærlighed. Ifølge Luther er det troen alene, der befrier synderen fra dens incurvatio in se og tillader et liv i kærlighed, i ens-væren-for-en-anden. Vantro vil føre tilbage til ufrihed, til synd som selvindkrogethed. Troen er nøglen til næstekærlighed. Luther signalerer, at det er helt afgørende at tro: "Tror du, så har du, og tror du ikke, så har du ikke" (9), hedder det i skriftet Om et kristenmenneskes frihed. Hvad er det, vi har i troen og ellers ikke? Luther forklarer, at alle egenskaber ved Guds ord bliver sjælens ejendom i tro (jf. 10), og metaforen om den frydefulde udveksling, kamp og bryllup mellem den menneskelige sjæl som brud og Kristus som dens brudgom lover, at sjælen bliver fri fra alle sine synder og får Kristi retfærdighed (jf. 12). Men hvis troen bliver kaldt "den eneste guddommelige gerning" (7), der alene vil retfærdiggøre alle, som har den, bliver troen så ikke igen en opgave, som enten lykkes eller mislykkes? Bliver troens gerning så ikke paralleliseret med kærlighedens gerninger? Det ville Luther ikke sige, fordi troens gerning i bund og grund ikke er menneskets, men Guds egen gerning. Vi kan ligeså lidt tro, som vi kan elske, hvis ikke Gud selv gør i os, hvad han kræver af os. Troens og kærlighedens gerninger er egentlig opera dei in nobis. Som mennesker kan vi ikke selv gøre os til troende og kærlige mennesker, og kun som troende kan vi forstå os selv som syndere. Tro og kærlighed er ikke noget, vi 'har' eller ' $g ø r$ ', men noget vi finder os $i$, når vi finder os i forholdet til Gud, der forholder sig til os, før vi kan forholde os til ham.

Ved første øjekast virker det, som om Kierkegaard er helt enig med Luther. I "Slutning" i hans bog om Kjerlighedens Gjerninger findes tanker, der har paralleller hos Luther, fx. "Dig skeer, som Du troer, har Du Troen til Frelse, saa frelses Du" (SKS 9, 371). Kierkegaard skriver eksplicit, at udtrykket stammer fra Jesu ord til høvedsmanden i Kapernaum: "Dig skee, som Du troede" (Matt 8,13, citeret efter NT af 1819, når bortses fra den petitesse, at 1819 har 'Dig' og 'Du' med lille begyndelsesbogstav). Men det reflekterer muligvis også Luthers udsagn: glaubstu, so hastu (WA 7, 24, 13) - tror du, så har du. 
Ifølge Luther får den troende noget, som man ikke kan besidde eller 'reservere' for sig selv, nemlig nåde, retfærdighed, fred og frihed, eller kort sagt: salighed. Hos Kierkegaard hedder det derimod, at 'det skal ske mennesket, som det tror'; dette 'som' forekommer ikke i Luthercitatet, men synes helt afgørende for Kierkegaards argumentation: “det holder saa stærkt igjen dette Næste 'som Du troer"” (SKS 9, 372, S.K.s fremhævelse). Kierkegaard tilføjer, at man her lige så godt kan prædike strenghed som mildhed. Troen er betingelsen for salighed. Så snart det er uvist, om jeg tror, forvandler frelsesvisheden sig til uvished. Dette er en bevægelse, der svarer til Luthers betoning af anfægtelsen, ${ }^{21}$ der hører med til troen (se afsnit 4-5).

Desuden kan det ikke udelukkes, at Kierkegaard var bekendt med Luthers skelnen mellem troens vished og sikkerhed, certitudo versus securitas. Han skriver, at man "i disse Tider [...] lader Daaben være Sikkerheden" og føjer til: "hvad den jo rigtignok ogsaa er, dersom Du virkeligen troer, at den er Sikkerheden 'Dig skeer som Du troer" (SKS 9, 372). Lidt efter fortsætter han: "Det er evigt vist, at Dig skeer som Du troer, men Troens Vished, eller den Vished, at Du, netop Du, troer, maa Du i ethvert Øieblik faae ved Guds Hjælp, altsaa ikke paa nogen udvortes Maade" (SKS 9, 372). ${ }^{22}$ Ydermere betoner han i overensstemmelse med Luthers princip sola gratia, at meningen ikke er, "at Mennesket saa dog til syvende og sidst fortjente Naaden. O, det Første Du lærer af i Alt at forholde Dig til Gud, er netop, at Du slet ingen Fortjeneste har" (SKS 9, 378).

Men ved nærmere undersøgelse opdager man også sætninger, der kan læses som en indirekte kritisk kommentar til den lutherske tradition. Kierkegaard vil vise, at vi ikke blot forholder os til andre mennesker, når vi har at gøre med dem, men at vi i alt forholder os til Gud, og at Gud gør mod os netop som vi gør mod andre. Det illustrerer han ved tilgivelsen: "Din Tilgivelse til en Anden er Din egen Tilgivelse; den Tilgivelse, Du giver, den faaer Du, ikke omvendt [...] Gud tilgiver Dig hverken mere eller mindre eller anderledes end som Du tilgiver Dine Skyldnere." (SKS 9, 373) Princippet 'lige for lige' er her ikke kun anvendt blandt mennesker, men udvidet til gudsforholdet. Dette implicerer, at Guds tilgivelse bliver ikke betinget, men eventuelt begrænset af menneskelig adfærd. Betragtet fra et luthersk perspektiv er det ret betænkeligt, fordi muligheden for at erfare Guds nåde bliver afhængig af det, vi mennesker gør. Luther ville sige, at Guds tilgivelse er det allerførste, som ikke er knyttet til nogen som helst for-

21. Jf. Johann Anselm Steiger, "Versuchung. Kirchengeschichtlich", Theologische Realenzyklopädie 35 (2003), 52-64.

22. Sandsynligvis polemiserer Kierkegaard her indirekte mod Grundtvigs vægtlægning på dåben, jf. kommentaren til stedet i SKS.K 9, 268f. 
udsætning og er fuldstændig uafhængig af menneskelig skyld eller gode gerninger eller mellemmenneskelig tilgivelse. Gud elsker syndere, selvom de $i k k e$ er elskværdige. Selvom Kierkegaard også vil hævde, at Guds tilgivelse kommer først, er det for ham afgørende at der alligevel bliver en sammenhæng tilbage mellem det vi gør og det vi bliver til.

Hvis ikke vi elsker hinanden, så ignorerer vi Gud, kærligheden selv, og så har vi ingen chance for at blive til en kærlig person, fordi vi får hvad vi giver og bliver til det vi gør. Ifølge Kierkegaard er troen ikke noget andet end kærlighed. Tro er kærlighed til Gud. Lige meget, om vi elsker Gud eller mennesker, elsker vi ved hjælp af kærlighedens ånd, dvs. Gud er altid med. Det er umuligt at elske uden at Gud er nærværende. Derfor er det også umuligt at tro på den usynlige Gud uden at elske dem vi ser. "Thi christeligt forstaaet er det at elske Menneskene at elske Gud, og det at elske Gud at elske Menneskene" (SKS 9, 376). Kierkegaard betragter troen og kærlighed som ens, som noget der sker samtidigt - således, at der ingen tro er uden kærlighed. Kærlighedens inderlighed er ikke andet end troens inderlighed, som i samme bevægelse vender sig indefter og udefter. Kærlighedens fordobling består netop i denne dobbeltbevægelse, der samtidig vender sig indefter og udefter, til Gud og til andre mennesker. Luther derimod præsenterer tingene sådan, at troen er forudgående og muliggør næstekærligheden. ${ }^{23}$ Luther lægger al vægt på troen, fordi der ingen næstekærlighed er uden troen. Troen udtrykker sin inderlighed udvortes i kærlighedens gerninger overfor næsten.

Når Kierkegaard udtrykkeligt kritiserer "den Smaalighed, der i disse Tider benytter Guds Kjerlighed til at sælge Aflad fra enhver farefuldere og mere anstrenget Stræben” (SKS 9, 378), så lægger han mærke til den historiske forskel mellem Luthers og hans egen tid. Luther har protesteret mod aflad, fordi Guds nåde var glemt, mens Kierkegaard minder om, at vores tiltro til Guds kærlighed ikke kan være en undskyldning for at slippe for alle anstrengelser. Nåden skal ikke modtages for billigt. Det, at man har at gøre med en nådig Gud, er ikke en selvfølge. Der erfares en dialektik mellem Guds strenghed og mildhed eller, sagt med Luthers ord: mellem Guds vrede og Guds

23. Tuomo Mannermaa har ganske vist argumenteret for troens og kærlighedens samtidighed. Alligevel må han indrømme, at menneskets tro er muliggjort af Guds kærlighed: set fra menneskets perspektiv er troen tidsligt forudgående og bør prioriteres, da både kærlighed til Gud og til næsten udspringer af troen. Jf. Tuomo Mannermaa, "Freiheit als Liebe", Freiheit als Liebe bei Martin Luther I Freedom as Love in Martin Luther: 8th International Congress for Luther Research in St. Paul, Minnesota, 1993: Seminar 1. Referate / Papers, red. Dennis D. Bielfeldt \& Klaus Schwarzwäller (Frankfurt am Main/Berlin/New York: Peter Lang 1995), 9-18, især 14. 
nåde og tilsvarende mellem lov og evangelium. Således fokuserer Kierkegaard på troens vanskelighed og faren, der ligger i, at man forventer at få kærlighed fra andre i stedet for at man selv kultiverer kærlighed. Kierkegaard gør klart, at Gud ikke lader sig spotte. Gud gengiver, hvorledes vi er, og i ethvert øjeblik uendeliggør han det, der er i os. Denne drastiske beskrivelse af gudsforholdet rejser spørgsmålet, om Gud kun er et "Echo" og gengivelse af mennesket. Hvis ikke Gud kan være anderledes end vi er og end vi tror han er, hvordan kan Kierkegaard så forhindre, at Gud forstås konstruktivistisk som menneskets 'projektion'? Argumentet mod sådan en fortolkning er ikke mindst, at slutningen af Kjerlighedens Gjerninger viser en yderste konsekvens af tanken om den evige kærligheds fordobling.

\section{Tro som tillid til Guds usynlige nærvær på trods af uvished}

Lad os nu komme tilbage til det spørgsmål, som jeg stillede i begyndelsen: Hvad skal der til, for at vi bliver i stand til at elske i frihed? Hvordan bliver kærlighedens bud til kærlighedens praksis? Hverken Luther eller Kierkegaard bygger på følelser, dyd og menneskelig formåen. Ingen af dem bygger på vores egen handlekraft, men på Guds kærlighed, der kommer frem i næstekærligheden. Hvordan skal vi gøre rede for den guddommelige dimension, der er involveret i mellemmenneskelig kærlighed?

For Luther og Kierkegaard er dette ikke primært et teoretisk, men et praktisk spørgsmål, nemlig spørgsmålet om, hvordan vi forholder os til Gud. Dette angår alle aspekter af menneskelig eksistens, fordi intet kan reserveres som et 'rent menneskeligt' anliggende, hvis Gud er allestedsnærværende. Luther og Kierkegaard er enige i, at den rigtige respons er troen, troen som tillid til Guds usynlige nærvær, tillid på trods af uvished.

I Den store katekismus (1529) behandler Luther de ti bud og beskriver under det første bud, hvad det betyder at tro på Gud: "En Gud vil sige det, hvoraf man venter sig alt godt, og som man tager sin tilflugt til i al nød. At have en Gud er altså ikke andet end af hjertet at stole på ham og tro ham, sådan som jeg ofte har sagt, at alene hjertets tillid og tro frembringer Gud og afgud. Er troen og tilliden ret, så er også din Gud ret, og omvendt, hvor tilliden er falsk og uret, dér er den rette Gud heller ikke. For de to hører sammen: tro og Gud. Det, dit hjerte hænger ved, det, du stoler på, det er egentlig din Gud."24

24. Jf. Martin Luther, Den store katekismus. Oversættelse, indledning og noter ved Leif Grane (København: Credo Forlag 2005), 42-50, 42, jf. WA 30/I, 125-238. 
Her kan vi høre, at tilliden i sig selv er tvetydig. Den kan rette sig mod Gud eller mod en afgud, f.eks. penge, livsforsikringen, eller noget andet, der før eller senere vil skuffe os, hvis vi hænger hjertet ved det. Alligevel hører tillid med til troen, idet troen viser vejen til Gud og giver adgang til hans hjerte. I sin forelæsning om Galaterbrevet skriver Luther ganske radikalt, at troen skaber guddommen - dog ikke i Gud selv, men i os: fides "creatrix est divinitatis, non in substantia Dei, sed in nobis" (WA 40/1, 360). Om vi tror på Gud eller ej, er han nærværende. Menneskelig tro har ikke indflydelse på Guds 'eksistens' - men uden troen glemmer vi alt om Gud eller tager $i$ hvert fald ikke hensyn til hans nærvær i vores liv.

Kierkegaard fremhæver ligeledes, at troen er knyttet til Gud i os, in nobis, fordi Gud ikke står foran øjnene af os og ikke kan ses på gaden. Hans usynlighed i den ydre verden er grunden til, at vi ikke kan garantere, at Gud er der, og anledningen til, at den subjektive tillid til Gud medfører objektiv uvished. Med andre ord: det troende subjekt kan ikke pege på troens genstand, fordi den er ikke synlig 'herude', men erfares 'heri', i menneskets inderste.

Kierkegaard nævner det i slutningen af Kjerlighedens Gjerninger: "Men Alt hvad der i Dig er af Kjød og Blod og Vedhængen ved det Jordiske og Frygtagtighed maa fortvivle, at Du ikke kan faae en udvortes Vished, en Vished én Gang for alle, og paa den nemmeste Maade. See, dette er Troens Strid, som Du hver Dag kan faae Anledning til at forsøges i” (SKS 9, 196). Troen bliver prøvet, hvad enten det fremprovokerer en endnu mere inderlig tro eller troen opgives. Igen er det en luthersk forestilling, at vi kæmper en daglig kamp med os selv, mens troen er i vækst og i anfægtelse.

I det Afsluttende uvidenskabelig Efterskrift til de philosophiske Smuler $(1846)^{25}$ henviser Kierkegaards pseudonym Johannes Climacus til troens risiko. Han accentuerer især troens modalitet, eftersom dens genstand ikke kan gribes. Troen har ingen objektivitet, men er subjektivitetens sag: "Objektivt accentueres: hvad der siges; subjektivt: hvorledes det siges. [...] den objektive Uvished, fastholdt $i$ den meest lidenskabelige Inderligheds Tilegnelse, er Sandheden, den højeste Sandhed der er for en Existerende. [...] Men den givne Bestemmelse af Sandhed er en Omskrivning af Tro. Uden Risico ingen Tro. Tro er netop Modsigelsen mellem Inderlighedens uendelige Lidenskab og den objektive Uvished. Kan jeg objektivt gribe Gud, saa troer jeg ikke, men netop fordi jeg ikke kan det, derfor maa jeg troe [...]” (SKS 7, 185-187).

25. Jf. Søren Kierkegaard, Afsluttende uvidenskabelig Efterskrift til de philosophiske Smuler (SKS 7), udg. af Søren Kierkegaard Forskningscenteret (København: Gads Forlag 2002). 
Troens sandhed er altså subjektiv. Den klassiske definition af sandhed som adaequatio intellectus et rei kan ikke appliceres på troen, fordi vi ikke kan overskue, om der faktisk findes en overensstemmelse mellem tænken og væren. Hvis vi bare tænker, at den findes, så er sandheden abstrakt bestemt som et færdigt tankeprodukt. I virkeligheden er den dog ikke færdig, fordi vi ikke er færdige. For os drejer det sig om at leve i sandheden uden at fastlægge sandhedens objekt. Problemet er så, at vi forefinder os i usandheden. Vores gudsforhold er ikke i orden. Det er stadig i sin vorden. Hvis vi anerkender det, anerkender vi, at vi er syndere, og at vores frihed er en fristet frihed.

\section{Frihedens fristelse, kærlighedens prøvelse og anfægtelsens nødvendighed}

For mig var det spændende at opdage, at både Luther og Kierkegaard ser en sammenhæn mellem frihedens fristelse, kærlighedens prøvelse og anfægtelsens nødvendighed. Denne sammenhæng vil jeg ganske kort skitsere, før jeg kommer til konklusionen.

Hvori består frihedens fristelse? Det bliver tydeligt ex negativo, hvis vi tænker på, hvilken form frihed egentlig skal have. Luther beskriver den kristne frihed som samvittighedens frihed. Samvittighedens frihed er frihed fra gode gerninger - ikke i den forstand, at man ikke skal gøre dem, men i den forstand, at man ikke skal stole på dem. ${ }^{26}$ Så snart vi stoler på vores egne værker, dyrker vi selvtillid i stedet for tillid til Gud. Denne forskel er vigtig, fordi vi ikke selv kan befri os fra konsekvenserne af det vi gør, når det går galt. Gud kan heller ikke gøre det, der er sket, til noget der ikke er sket. Vi kan ikke aflaste os ved at lade sorteper gå videre. Vi er ansvarlige for det vi har gjort, og skylden kan ikke bare gives til en anden. Men Gud giver mulighed for fornyelse, fordi han ikke blot betragter os som syndere, som 'gamle' mennesker. Han er den eneste, der kan forvandle os til nye skabninger. Troen medfører en god samvittighed, fordi evangeliet er det afgørende ord, der retfærdiggør en person på trods af hans gode eller onde gerninger og på trods af hans selv-fordømmelse.

Samvittigheden er i sig selv en tvetydig dømmekraft. Man kan ikke forlade sig på, at dens dom er rigtig. Den ikke bare bedømmer, hvad vi gør, men også, hvem vi er. Luther mener ikke, at samvittigheden skal få højeste autoritet. Når samvittigheden bliver selvretfærdig, op-

26. WA 8, 606, 30f: "Est itaque libertas Christiana seu Euangelica libertas conscientiae, qua solvitur conscientia ab operibus, non ut nulla fiant, sed ut in nulla confidat." 
kaster den sig selv til en gud, eller rettere sagt, en afgud. Når samvittigheden fordømmer os, skal vi huske, at Gud er større end vores eget hjerte. I Den store katekismus advarer Luther mod det farlige, der ligger i samvittighedens fejltagelse: "Derudover findes der også en falsk gudstjeneste, som er det højeste afguderi, vi hidtil har bedrevet, ja, det styrer stadig verden; på det bygger alle ordener. Det vedrører alene samvittigheden, idet det søger hjælp, trøst og salighed i egne gerninger, fordrister sig til at ville tiltvinge sig plads i himlen af Gud, opregner mængde og størrelsesorden af fromme stiftelser, faster, messer osv. Man forlader sig på alt dette og pukker på det over for Gud, som om man ikke vil tage imod noget fra hans side, men selv erhverve alt og fortjene det ved overskydende gerninger, så det må se ud, som om Gud skulle stå til vor tjeneste og være vor skyldner, medens vi er hans lensherrer. Hvad er det andet end at gøre Gud til en afgud og regne sig selv for og opkaste sig til gud?" (Luther 2005, 45f) Synden optræder her som superbia. Synderen vil selv gerne være som Gud, nemlig perfekt, men vil ikke tage imod det gode Gud giver gratis. Det er farligt, fordi synderen så mener, at han ikke har brug for Guds kærlighed. Synderen tror på sig selv i stedet for på Gud.

Omvendt hører det til troen, at den anfægtes. Hvorfor er det nødvendigt? ${ }^{27}$ Kun den troendes tro kan anfægtes. Ifølge Luther er anfægtelsen nødvendig, fordi man ellers ikke vil søge trøst i Guds ord, men vil fortsætte med at leve i en falsk følelse af sikkerhed. Han sammenligner den barmhjertige Gud, der virker som den vrede Gud, med solen, der nogle gange skjuler sig bag skyerne, men alligevel forbliver solen (jf. WA 31/I, 553f). Gud virker også der, hvor det ser ud, som om det var djævelen. Gud anfægter for at vi skal bestå; djævelen anfægter for at vi skal falde og fortvivle. ${ }^{28}$ Problemet er, at vi ikke kan skelne mellem de to, når vi er midt $\mathrm{i}$ anfægtelsens erfaring. Men til sidst vil Gud vise sig som den, der også havde styr på Satan.

I mellemtiden er det dog svært at genkende den sande Gud, når han skjuler sig. Modsiger Gud sig selv? Er han ikke længere kærlighed? 1 Mos 22 fortæller historien om Abrahams konfrontation med Guds selv-modsigelse. ${ }^{29}$ På den ene side havde Gud lovet, at Abra-

27. Jf. Johann Anselm Steiger, "Ad Deum contra Deum. Zur Exegese von Genesis 22 bei Luther und im Luthertum der Barockzeit", Opfere deinen Sohn! Das ,Isaak-Opfer' in Judentum, Christentum und Islam, red. Bernd Janowski m.fl. (Tübingen: Narr Francke Attempto 2007), 135-154.

28. Jf. WA 37, 310, 5f: "Sic deus tentat te, ut fortiter perstes, econtra diabolus, das du umbfallest."

29. Jf. WA 43, 201, 30-32: "Deus enim manifeste hic sibi ipsi contradicit: quomodo enim conveniunt haec: 'in Isaac vocabitur tibi semen', et: 'tolle filium tuum, et macta eum'." 
hams efterkommere skulle blive så mange som stjernerne på himlen, på den anden side opfordrer han ham nu til at ofre sin eneste søn. Det er ikke bare Abrahams tillid, der underkastes en prøvelse, men også sandheden af Guds tilsagn. Det, der står på spil, er spørgsmålet, om Gud er pålidelig eller ej. Hvad skal man gøre i sådan en situation? Luther svarer: man skal flygte "ad deum contra deum" (WA 5, 204, 26f), til den åbenbare Gud væk fra den skjulte Gud. Man skal fastholde hans løfte, selvom Gud ikke gør det. Det gælder om at overvinde Gud ved hjælp af hans eget ord, hans forjættelse, hans promissio. ${ }^{30}$ Gud selv må vise, om han holder ord. Det, der ser ud som fristelsen af Abrahams tro, er egentlig prøvelsen af Guds kærlighed.

Abrahams historie står som bekendt også centralt i Kierkegaards forfatterskab. Hans pseudonym Johannes de silentio introducerer historien i Frygt og Baven (1843) på følgende måde: "I vor Tid bliver Enhver ikke staaende ved Troen, men gaaer videre. [...] I hine gamle Dage var det anderledes, da var Troen en Opgave for hele Livet, fordi man antog, at den troende Færdighed ikke erhverves hverken i Dage eller Uger. Naar da den prøvede Olding nærmede sig sit Endeligt, havde stridt den gode Strid og bevaret Troen, da var hans Hjerte ungt nok til ikke at have glemt hiin Angst og Bævelse, der tugtede Ynglingen, som Manden vel beherskede, men som intet Menneske ganske voxer fra - uden forsaavidt det skulde lykkes ved saa tidlig som mulig at gaae videre." 31 Den troende må kæmpe hårdere end alle andre. Han kæmper ikke kun med almenmenneskelige sorger og bekymring, med hårde livsvilkår, med sygdom, tab og smerte. Han kæmper med Gud selv. Johannes de silentio siger, at han ikke kan forstå Abraham. Abrahams tro kan kun forstås som forståelsens grænse. ${ }^{32}$ Man kan kun lære denne tro at kende, hvis man fordyber sig i troens paradoks (jf. SKS 4, 207). Troen er et ydmygt mod, der tror i kraft af det absurde, at for Gud er alting muligt, selvom menneskelig fornuft ikke ser nogen muligheder mere (jf. SKS 4, 141, 143).

Kapitel V i Begrebet Angest beskriver troen på en lignende måde. Her er troen defineret som "den indre Vished, der tager Uendeligheden forud" (SKS 4, 456). Denne indre vished er ikke givet en gang for alle. Den skal gå igennem angsten. Den skal få mod til angsten. Angsten skal ængste det endelige og smålige ud af den troende, som

30. Jf. WA 24, 386, 17-24: "Also müssen wir yhn überwinden mit seinem eygenem wort, das ist fast der höhiste kampff und streit, wilchen die heiligen veter wol geübt haben."

31. Søren Kierkegaard, Frygt og Beven (SKS 4), udg. af Søren Kierkegaard Forskningscenteret (København: Gads Forlag 1997), 102f.

32. Jf. Iben Damgaard, At lege fremmed med det kendte. Kierkegaards gendigtninger af bibelske figurer (København: Forlaget Anis 2008), 57-88. 
ved angsten skal dannes til den rette tro (jf. SKS 4, 458), der gør, at den troende kan "hvile i Forsynet" (SKS 4, 459) og "i Forsoningen" (SKS 4, 461). Kierkegaard følger igen Luther, når han refererer til den ængstede samvittighed (jf. Pap. VII 1 A 192, fra 1846), der er blevet bange - bange for sig selv, for frihedens afgrund, og bange for den skjulte Gud.

Hvorfor skjuler Gud sin kærlighed? I den allerførste tale i Kjerlighedens Gjerninger ("Kjerlighedens skjulte Liv og dets Kjendelighed paa Frugterne") bemærker Kierkegaard problemet, at det ydre skin er inkommensurabelt med kærlighedens inderlighed. Man kan ikke se kærlighed med sanserne - man må tro på den, fordi den ikke har et entydigt kendetegn. Intet tegn kan bevise dens tilstedeværelse eller at den ikke er der (jf. SKS 9, 13, 22). Dette gælder også for Guds kærlighed. Med hensyn til kærligheden mellem mennesker afslutter Kierkegaard kapitlet ved at slå fast: "Det sidste, det saligste, det ubetinget overbevisende Kjende paa Kjerlighed bliver derfor: Kjerligheden selv, som bliver kjendt og gjenkjendt af Kjerligheden i en Anden. Det Lige kjendes kun af det Lige; kun Den, der bliver i Kjerlighed, kan kjende Kjerligheden, ligesom hans Kjerlighed er til at kjende." (SKS 9, 24) Det vil sige: Kun én, der elsker, kan se kærligheden i en anden. Kun én, der elsker Gud (dvs. den troende), kan genkende hans kærlighed, selvom den skjuler sig i noget andet - eller sågar sub contrario, i det modsætte.

Hvad er meningen med det? Mener Kierkegaard, at kærlighed er skjult, fordi der skal komme én, der er kærlig nok til at opdage, hvad der ligger under masken? Skal skjultheden af den enes kærlighed fremprovokere kærligheden i en anden? Kan det lykkes? Der er passager, der tyder på, at Kierkegaard mener netop det. De passager findes i talen med titlen "Kjerlighed er Samvittighedens Sag" (Tale I.III.B). Kristendommen vil "prøve Troen i den Enkelte, prøve, om den Enkelte vil bevare og nøies med Troens Hemmelighed. Det Verdslige trænger altid paa Afgjørelse i det Udvortes, mistroisk troer det ellers ikke paa, at Afgjørelsen er til. Men denne Anledning til Mistroiskhed er netop Anfægtelsen, hvori Troen skal prøves. Verdsligt forstaaet vilde det ogsaa være langt sikkrere for at faae det afgjort og for at være ganske sikker paa, at der er en Gud til, at have et Billede af ham stillet op - saa kunde man da see, at han var til? eller at en Afgud var til? som dog heller ikke er til. [...] Verdslig Misforstaaelse trænger paa, for at faae det udtrykt i det Udvortes, at Kjerlighed christeligt er Aands Kjerlighed - ak, men dette kan ikke udvortes udtrykkes i nogen Udvorteshed, thi det er netop Indvorteshed." (SKS 9, 147) Denne passage forklarer, at troens anfægtelse ikke kun er troens, men først og fremmest kærlighedens prøvelse. Kierkegaards fremstilling af 
uvisheden på grund af Guds usynlighed og alternativet mellem Gud og afgud, der begge to kan blive det vi stoler på, ligner Luthers forklaring af det første bud. Kærlighed som ånd kan være til stede alle steder, men hvis den var synlig, så førte den til idolatri. Troens tillid retter sig mod det usynlige, usikre, ubeviselige.

I tale II.II "Kjerlighed troer Alt - og bliver dog aldrig bedragen" udvider Kierkegaard synsfeltet og siger, at "Tilværelsen" (NB: ikke kun kristendommen) skal prøve, "om der er Kjerlighed i Dig”, og derfor "sætter den Dig ved Forstandens Hjælp det Sande og Bedraget i de hinanden modsatte Muligheders Ligevægt, at det, idet "Du" nu dømmer [...], maa blive aabenbart, hvad der boer i Dig" (SKS 9, 229) - nemlig enten mistroiskhed eller kærlighed. Den kærlige vælger at tro på det gode, fordi det er muligt, at en andens slethed kun var tilsyneladende, mens den mistroiske mener, man ikke skal tro, fordi det var muligt, at sågar det bedste menneske var en bedrager (jf. SKS 9, 230). Og - sådan kunne man digte videre - det var dog også muligt, at den sande Gud var Dracula. Mistroens fantasi har ingen grænser.

\section{Konklusion}

Hvad er så resultatet af disse overvejelser? Kierkegaard forsøger at forny og reformere den paulinsk-lutherske tradition med hensyn til menneskesynet og gudsforholdet, idet han genfortolker (1) forholdet mellem det 'indre' og 'ydre', (2) det 'gamle' og 'nye' menneske og (3) forholdet mellem tro og kærlighed.

Ad 1) Det lykkes Kierkegaard at fastholde Paulus' modsætning af sarx og pneuma uden at forbeholde begrebet 'and' til det 'indre' menneske. Snarere ser han ånden som det, der forbinder menneskets krop og sjæl til en uadskillig helhed, der enten lader sig bestemme af Guds ånd eller af egenmægtighed. Kierkegaards syn af selvet som selvforhold tillader, at kærlighedens 'inderlighed' forstås som en bestemt måde at være til og at handle på, der modstår synderens selvindkrogethed, dvs. tendensen til selviskhed, der viser sig $i$ dens forhold til andre mennesker, til omverdenen og til Gud. Dermed korrigeres en mulig misforståelse af Luthers tese om et kristenmenneskes dobbelte, 'indre' og 'ydre' natur. Det 'indre' menneske kan hverken reduceres til det mentale, sjælelige liv, eller identificeres med det nye menneske på sådan en måde, at kroppen bliver efterladt som det 'gamle' legemlige menneske.

Ad 2) Hvad angår forholdet mellem det 'gamle' og det 'nye' menneske, så vægrer Kierkegaard sig at overtage Luthers idé om, at men- 
nesket er udleveret til enten Guds eller djævelens magt. Ifølge Kierkegaard er mennesket et handlende subjekt ikke bare forhold til jordiske anliggende, men også i forhold til Gud. Dets frihed ligger i det, at kunne forholde sig til det, der sker og det, det gør. Samtidig holder Kierkegaard fast i den overbevisning, at menneskets frelse ikke skyldes dets egen indsats. Selvom det gamle menneskes ufrihed er fortolket som et frihedens fænomen, er det nye menneskes frihed ikke dets egen fortjeneste, men snarere en gave, der modtages mere passive.

Ad 3) Mens Kierkegaard er enig med Luther i hans prioritering af Guds kærlighed, der fremelsker menneskets kærlighed, følger han ikke Luther i hans prioritering af troen over for næstekærlighed. Kierkegaard anvender princippet 'lige for lige' også når der er tale om tilgivelse. Hvad vi gør i forhold til andre mennesker virker tilbage på os selv, fordi troen som kærlighed til Gud ikke er en anden form for kærlighed end mellemmenneskelig kærlighed. Hvis vi ikke elsker næsten, elsker vi heller ikke Gud, og hvis vi ikke elsker Gud, kan vi heller ikke elske naboen. Ifølge Kierkegaard giver Gud igen, i forhold til hvad vi gør og hvordan vi er, ${ }^{33}$ mens han ifølge Luther kommer al vores gøren og væren i forkøbet og kan skænke tilgivelse også til synderen, der endnu ikke har tilgivet sin bror. Kierkegaards understregning af troens vanskelighed afspejler den historiske forskel mellem hans og Luthers tid.

Alligevel er Luther og Kierkegaard enige på følgende punkter: Frihed til kærlighed forudsætter frihed fra bekymringen om sig selv. Denne frihed findes i troen, i tiltro til Gud som vor tilflugt i al nød. Frihedens største fristelse er at opgive troen, at opgive kærligheden og at opgive håbet. Fristelsen kommer ikke altid 'udefra'. Vi kan forholde os på forskellige måder til det, vi møder 'derude' og til det vi går igennem. Den største fristelse kommer 'indefra' - nemlig fristelsen til ikke at have mod til at modtage livet. Troen er denne fristelses modstander. Troen er derfor aldrig uden kamp. Den troende ser sig selv som en retfærdiggjort synder, og synderens største fjende er jo - ja, ham selv. Den troende må regne med anfægtelse. Den er nødvendig for at få frem, hvad der ligger i mennesket, og for at åbenbare, at Guds kærlighed bliver til alligevel. Den, kærligheden altså, forbliver usynlig, men som sådan kan den være til stede overalt - også på steder, hvor vi ikke forventer det. ${ }^{34}$

33. Gud gengiver menneskets væren. Jf. SKS 9, 377: "Thi Gud er egentligen selv dette rene Lige for Lige, den rene Gjengivelse af hvorledes Du selv er."

34. En særlig tak til Anna Vind, både for sproglige rettelser og indholdsmæssige diskussioner, og til de to anonyme forfattere af peer reviews, hvis kommentarer har hjulpet til at forbedre artiklen på centrale punkter. 